\title{
Judicial Supremacy and the Modest Constitution
}

\author{
Frederick Schauer ${ }^{\dagger}$
}

\section{INTRODUCTION}

Judicial supremacy is under attack. From various points on the political spectrum, political actors as well as academics have challenged the idea that the courts in general, and the Supreme Court in particular, have a special and preeminent responsibility in interpreting and enforcing the Constitution. Reminding us that treating Supreme Court interpretations of the Constitution as supreme and authoritative has no grounding in constitutional text and not much more in constitutional history, these critics seek to relocate the prime source of interpretive guidance. The courts have an important role to play, these critics acknowledge, but it is a role neither greater than that played by other branches, nor greater than the role to be played by "the people themselves."

The critics' understanding of a more limited function for the judiciary in constitutional interpretation appears to rest, however, primarily on a highly contestable conception of the point of having a written constitution in the first place. According to this conception, a constitution, and especially the Constitution of the United States, is the vehicle by which a democratic polity develops its own fundamental values. A constitution, therefore, becomes both a statement of our most important values and the vehicle through which these values are created and crystallized. Under this conception of the role of a written constitution, it would indeed be a mistake to believe that the courts should have the preeminent responsibility for interpreting that constitution. For this task of value generation to devolve

Copyright $(\mathcal{C} 2004$ California Law Review, lnc. California Law Review, Inc. (CLR) is a California nonprofit corporation. CLR and the authors are solely responsible for the content of their publications.

$\dagger$ Frank Stanton Professor of the First Amendment, John F. Kennedy School of Government, Harvard University. This is the written version of a commentary delivered at the Brennan Center's Jorde Symposium, held at the University of Michigan Law School on April 4, 2003. An earlier version was presented at the Kennedy School of Government's Faculty Research Seminar. Although this Reply goes in a slightly different direetion from my joint work with Larry Alexander, it is part of our larger project on judieial supremacy and a product of our discussions and collaboration. Research support was provided by the Joan Shorenstein Center on the Press, Politics \& Public Policy.

1. Larry D. Kramer, Popular Constitutionalism, circa 2004, 92 CALif. L. Rev. 959, 959 (2004). 
to the courts would represent not only a perversion of constitutionalism, so the argument goes, but would also signal an abdication of democratic governance itself.

Although such a conception is not without merit, it must compete with an alternative and arguably superior understanding of the raison d'etre of a written document called a "constitution." Under this alternative understanding, the constitution incorporates a series of rules that impose secondorder constraints on the first-order policy preferences of the people and of their elected representatives and executive officials. ${ }^{2}$ Precisely because these second-order constraints limit (in the service of longer-term or deeper values) the rational and usually well-meaning first-order preferences of those who are to be constrained, it would be anomalous to place too much hope or trust in those whose constraint is the whole point of the constitutional limits. Under this alternative view of constitutionalism, judicial supremacy emerges not because of any nostalgic or unduly idealistic view about the capacities of the judiciary. Nor does it flow from contempt for the decision-making capacities of ordinary people. Rather, external constraint on those who are to be constrained from effectuating even their rational, well-meaning, and good-faith policies and preferences is the natural concomitant of the external nature of the constitutional norms themselves. In this Reply I seek to explicate and defend this latter version of constitutionalism and thus to show that the judicial role labeled "judicial supremacy" is the natural partner of constitutionalism itself.

I

\section{Two Preliminaries \\ A. Authority and Supremacy}

The question here is one that often rides under the banner of "judicial supremacy," 3 but it is better understood as being more about judicial

2. The distinction between first- and second-order reasons is a familiar one in moral, political, and legal theory, with the basic idea being that second-order reasons serve to exclude otherwise good first-order reasons, or to include otherwise bad first-order reasons. This basic idea has an affinity with H.L.A. Hart's distinction between primary and secondary rules, H.L.A. HART, THE CONCEPT OF LAW 79-99 (2d ed. 1994), was developed at some length in the works of Joseph Raz, see, e.g., JOSEPH RAZ, Practical Reasons and Norms 15-48 (1990); Joseph Raz, The Authority of Law: Essays on Law and Morality 3-33 (1979); Joseph Raz, The Morality of Freedom 23-37 (1986), and is summarized and developed further in, for example, Frederick SCHAUER, Playing By the Rules: A Philosophical Examination of Rule-Based Decision-Making in Law and in Life 88-93 (1991); Cass R. Sunstein \& Edna Ullman-Margalit, Second-Order Decisions, 110 ETHICs 5 (1999). At the heart of the distinction between first-order and second-order reasons is the idea that excluding first-order reasons may at times better protect the long-term values embodied in second-order reasons and may at other timcs prevent those first-order decisions that would simply be mistaken at the outset.

3. See, e.g., Larry Alexander \& Frederick Schauer, Defending Judicial Supremacy: A Reply, 17 Const. Comment. 455 (2000); Rachel E. Barkow, More Supreme Than Court? The Fall of the Political Question Doctrine and the Rise of Judicial Supremacy, 102 ColuM. L. REv. 237 (2002); Neal Dcvins \& Louis Fisher, Judicial Exclusivity and Political Instability, 84 VA. L. REv. 83 (1998); Scott 
authority than about judicial supremacy. Although it is not inaccurate to refer to "supremacy," there is some risk of misunderstanding, a risk I will try to minimize at the outset. Thus, consistent with standard understandings of the concept of authority, ${ }^{4}$ the question is whether Supreme Court interpretations of the Constitution (and with some caveats lower court interpretations as well) ${ }^{5}$ should be understood by other branches of government, and by the people, as authoritative-as being entitled to deference not (necessarily) because of their wisdom, but solely because of their source.

This source-based understanding of authority and thus of authoritativeness makes clear the important way in which authoritativeness differs from persuasiveness. Of course Supreme Court interpretations of the Constitution may be persuasive because of their reasoning or their outcome, but so too may historical statements, law review articles, judicial decisions of other nations, newspaper op-eds, and the arguments made by our friends and relatives. If the question is only whether Supreme Court decisions ought to be respected when they are persuasive, then there is no serious argument at all, for no one would contend that persuasive Supreme Court opinions should not be respected when they persuade on the merits.

E. Gant, Judicial Supremacy and Nonjudicial Interpretation of the Constitution, 24 HASTINGS Const. L.Q. 359 (1997); Barry Friedman, The History of the Countermajoritarian Difficulty, Part One: The Road to Judicial Supremacy, 73 N.Y.U. L. REv. 333 (1998); Edward A. Hartnett, A Matter of Judgment, Not a Matter of Opinion, 74 N.Y.U. L. Rev. 123 (1999); Larry D. Kramer, Foreword: We the Court, 115 HaRv. L. Rev. 4, 6-16 (2001); Robert Justin Lipkin, The New Majoritarianism, 69 U. CIN. L. REv. 107 (2000); Frank 1. Michelman, Living with Judicial Supremacy, 38 W AKE FOREST L. Rev. 579 (2003); L.A. Powe, Jr., The Politics of American Judicial Review: Reflections on the Marshall, Warren, and Rehnquist Courts, 38 WAKE FoREST L. REv. 697 (2003); Saikrishna B. Prakash \& John C. Yoo, The Origins of Judicial Review, 70 U. CHI. L. Rev. 887 (2003); Robert A. Schapiro, Judicial Deference and Interpretive Coordinacy in State and Federal Constitutional Law, 85 CORNELL L. REv. 656 (2000); Keith E. Whittington, Extrajudicial Constitutional Interpretation: Three Objections and Responses, 80 N.C. L. Rev. 773 (2002); Brian M. Feldman, Note, Evaluating Public Endorsement of the Weak and Strong Forms of Judicial Supremacy, 89 VA. L. REv. 979 (2003).

4. See, e.g., Richard T. De George, The Nature and Limits of Authority (1985); Authority (Joseph Raz ed., 1990); Raz, The Authority of LaW, supra note 2; Heidi M. Hurd, Challenging Authority, 100 Yale L.J. 1611 (1991); Donald H. Regan, Reasons, Authority, and the Meaning of "Obey": Further Thoughts on Raz and Obedience to Law, 3 CANADIAN J. L. \& JURISPRUDENCE, 3 (1990); Frederick Schauer, The Questions of Authority, 81 GEO. L.J. 95 (1992).

5. The issue of lower court interpretive authority is often discussed under the rubric of "nonaequiescence," the practice by which some federal agencies refuse to follow, exeept in the particular case, federal appellate court (but not Supreme Court) decisions the agency believes mistaken. See generally Samuel Estreicher \& Richard L. Revesz, Nonacquiescence by Federal Administrative Agencies, 98 YALE L.J. 679 (1989). The case for acquiescence (or nonacquiescence) in Court of Appeals decisions is made more complex by the following questions: (1) whether a Court of Appeals decision would be considered binding within the Circuit but not without, (2) whether there is a Supreme Court decision generally on the issue, and (3) whether the issue is likely to produce a Supreme Court decision in the foreseeable future. Thus, when the Fifth Circuit invalidated any use of race in admissions at the University of Texas Law School in 1996, in Hopwood v. Texas, 78 F.3d 932 (5th Cir. 1996), questions arose about the extent to which that decision, binding on the University of Texas Law School, and arguably binding on the state of Texas, should also be considered authoritative (and not merely persuasive) in other states within the Circuit, or even in other Circuits. 
But a true question of authority is content independent ${ }^{6}$ and therefore persuasiveness independent. The question is whether a Supreme Court opinion should be entitled to deference just because of its source and not (necessarily) because of its content or its persuasiveness, and thus even when it is not persuasive. Put most clearly, the question is whether there is an argument for following even those Supreme Court interpretations of the Constitution that the follower believes mistaken. ${ }^{7}$

Even if Supreme Court interpretations should be understood as authoritative, it does not follow that such authority should be absolute-that is, infinitely stringent. What makes the term "supremacy" potentially misleading is that the term may suggest absoluteness; it may imply that accepting the Supreme Court as the authoritative interpreter of the Constitution entails accepting that no considerations of morality, prudence, or anything else can ever override that authority. Although some have argued forcefully for such a position, ${ }^{8}$ the infinite stringency of an authority is not entailed by the concept of authority itself any more than the infinite stringency of a rule, an obligation, or a right is entailed by the authority and the existence of the rule, the obligation, or the right.. ${ }^{9}$ We could treat Supreme Court decisions as authoritative while recognizing that, on occasion, the wrongness of a Supreme Court interpretation will be so apparent and so immoral-Dred $S$ cott ${ }^{10}$ comes to mind-that the presumption of deference implicit in the concept of authority should be overridden. Thus, the key idea is that of a presumption, for although presumptions can be overcome by reasons of extraordinary strength, there is no reason to believe that presumptions - any more than heightened burdens of proofneed be incapable of being overcome in order to have substantial effect.

6. See H.L.A. Hart, Essays on Bentham: Studies in Jurisprudence and Political Theory 243-68 (1982); RaZ, The Morality of Freedom, supra note 2, at 35-37 (1986); Gerald J. Postema, Coordination and Convention at the Foundations of Law, 11 J. LEG. STUD. 165 (1982).

7. Much the same applies to the idea of precedent, for a precedent matters qua precedent only when the precedent follower believes the precedent mistaken on the merits. If the precedent follower believes the precedent sound, she could reach the same decision absent the precedent. But if the precedent follower believes the precedent unsound, its precedential force may still produce a decision consistent with the precedent when the precedent follower genuinely places weight on the precedent's precedential force. See Larry Alexander, Constrained By Precedent, 63 S. CAL. L. Rev. 1 (1989); Frederick Schauer, Precedent, 39 STAN. L. REv. 571 (1987).

8. See Emily Sherwin, Ducking Dred Scott: A Response to Alexander and Schauer, I5 ConsT. Comment. 65 (I998).

9. See A. John Simmons, Moral Principles and Political Obligations 7-28 (1979); Barty Loewer \& Marvin Belzer, Prima Facie Obligation: Its Deconstruction and Reconstruction, in JoHN SEarle ANd His Critics 359 (Ernest LePore \& Robert Van Gulick eds., I99I); Robert Noziek, Moral Complications and Moral Structures, 13 NAT'L L.F. 1 (1968); Frederiek Schauer, A Comment on the Structure of Rights, 27 GA. L. REv. 415 (1993); John Searle, Prima Facie Obligations, in Philosophical Subjects: Essays Presented to P.F. Strawson 238 (Zak van Straaten ed., 1980); Judith Jarvis Thomson, Some Ruminations on Rights, 19 ARIz. L. Rev. 45 (1977).

I0. Scott v. Sandford, 60 U.S. (19 How.) 393 (1856). 
Yet although the concept of authority does not entail the absoluteness of that authority, it does entail that some will have authority and others will not. In order for deference to be a coherent idea, " some individuals or institutions must be entitled to deference, and others not. It is in this sense of differential authority that the term "judicial supremacy" takes its meaning, for the question under consideration is whether Supreme Court (and other judicial) interpretations of the Constitution are to be understood as (presumptively) authoritative, whereas congressional, executive, administrative, or popular interpretations of the Constitution in general are not. The corollary question is whether Congress, the President, ${ }^{12}$ the administrative agencies, and the people should defer to Supreme Court interpretations of the Constitution even while the Supreme Court is not expected to defer to congressional, executive, administrative, and popular interpretations of the Constitution. ${ }^{13}$ This, as so clarified, is our question here, although at this point in the argument it should be understood only as no more than a question.

\section{B. The Political Valence (Or Not) of Judicial Supremacy}

Unlike many, perhaps most, constitutional debates, the debate about judicial supremacy does not appear to have an obvious political valence. Although several recent decisions of the Rehnquist Supreme Court have enthusiastically supported the idea of judicial supremacy, ${ }^{14}$ the debate goes back to the similar pronouncements about judicial supremacy in Cooper $v$. Aaron, ${ }^{15}$ an iconic decision of the Warren Court. More recently, although Professor Kramer and others who attack, or at least question, judicial

11. See Philip Soper, The Ethics of Deference: Learning from Law's Morals (2002).

12. See David S. Strauss, Presidential Interpretation of the Constitution, 15 Cardozo L. Rev. 113 (1993).

13. That judicial supremacy is the default position does not mean that there cannot be particular instances in which the deference runs in a different direction, which is the whole point of the "textually demonstrable constitutional commitment ... to a coordinate political dcpartment," Baker v. Carr, 369 U.S. 186, 217 (1962), strand of political question doctrine. See Nixon v. United States, 506 U.S. 224 (1993); Goldwater v. Carter, 444 U.S. 996 (1979); Powell v. McCormack, 395 U.S. 486 (1969); Coleman v. Miller, 307 U.S. 433 (1939). And even when there is no such "textually demonstrable commitment," therc are areas, especially in the context of war, foreign policy, and national security, in which the courts appear to have abandoned the default rule of judieial interpretive authority. See Dames \& Moore v. Regan, 453 U.S. 654 (1981).

14. See, e.g., Bd. of Trs. of Univ. of Ala. v. Garrett, 531 U.S. 356 (2001); Kimel v. Fla. Bd. of Regents, 528 U.S. 62 (2000); United States v. Morrison, 529 U.S. 598 (2000); Dickerson v. United States, 530 U.S. 428 (2000); City of Boerne v. Flores, 521 U.S. 507 (1997). For critique, see Susan Bandes, Fear and Degradation in Alabama: The Emotional Subtext of University of Alabama v. Garrett, 5 U. PA. J. CoNST. L. 520 (2003); Kramer, supra note 3; and Robert C. Post \& Reva B. Siegel, Protecting the Constitution from the People: Juricentric Restrictions on Section Five Power, 78 IND. L.J. 1 (2003).

15. 358 U.S. 1 (1958). 
supremacy ${ }^{16}$ might loosely be thought of as lying to the left of center in contemporary American politics, the contemporary academic attack on judicial supremacy was in fact initiated by conservatives such as Michael Paulsen ${ }^{17}$ and Gary Lawson. ${ }^{18}$ Moreover, the position espoused by Professors Kramer and Paulsen, among others, was embraced in 1986 by Ronald Reagan's Attorney General, Edwin Meese III, ${ }^{19}$ as well as by those with $^{20}$ and without ${ }^{21}$ sympathy for Meese's general political outlook. Even apart from Meese's speech, challenges to judicial supremacy were Justice Department policy throughout the administrations of Ronald Reagan and George H.W. Bush, ${ }^{22}$ and were a central focus of conservative plans at the beginning of President George W. Bush's administration. ${ }^{23}$ Yet, in the past, challenges to judicial authority in constitutional interpretation have been embraced just as enthusiastically by Presidents Abraham Lincoln ${ }^{24}$ and Franklin Roosevelt. ${ }^{25}$

Although the foregoing lineup ignores important complications and variations that will reappear later in the analysis, ${ }^{26}$ the bipartisan history of

16. Mark Tushnet, Taking the Constitution Away from the Courts (1999); Robert Post, The Supreme Court, 2002 Term-Foreword: Fashioning the Legal Constitution: Culture, Courts, and Law, 117 Harv. L. Rev. 4 (2003); Robert C. Post \& Reva B. Siegel, Legislative Constitutionalism and Section Five Power: Policentric Interpretation of the Family and Medical Leave Act, 112 YALE L.J. 1943 (2003); Post \& Siegel, supra note 14; Mark Tushnet, Two Versions of Judicial Supremacy, 39 WM. \& MARY L. REv. 945 (1998).

17. Michael Stokes Paulsen, The Most Dangerous Branch: Executive Power to Say What the Law Is, 83 GEO. L.J. 217 (1994).

18. Gary Lawson \& Christopher D. Moore, The Executive Power of Constitutional Interpretation, 81 IOWA L. REv. 1267 (1996).

19. Originally a speech, the written version is Edwin Meese 111, The Law of the Constitution, 61 TUL. L. REv. 979 (1987). The speech as well as commentaries and background materials can also be found in Who Speaks for the Constitution? The Debate Over INTERPretive Authority (Federalist Soc'y for L. \& Pub. Pol'y Stud. Occasional Paper No. 3, 1992), and in Perspectives on the Authoritativeness of Supreme Court Decisions, 61 TuL. L. REv. 977 (1987).

20. See Rex E. Lee, The Provinces of Constitutional Interpretation, 61 TuL. L. REv. 1009 (1987); Robert Nagel, The Role of the Legislative and Executive Branches in Interpreting the Constitution, 73 CORNELl L. Rev. 380 (1988).

21. See Sanford Levinson, Could Meese be Right This Time?, 61 Tul. L. REv. 1071 (1987); see also Paul Brest, Congress as Constitutional Decisionmaker and Its Power to Counter Judicial Doctrine, 21 GA. L. REv. 57 (1986); Paul Brest, The Conscientious Legislator's Guide to Constitutional Interpretation, 27 STAN. L. REv. 585 (1975); Stephen L. Carter, The Morgan "Power" and the Forced Reconsideration of Constitutional Decisions, 53 U. CHI. L. REv. 819 (1986).

22. See Dawn E. Johnsen, Ronald Reagan and the Rehnquist Court on Congressional Power: Presidential Influences on Constitutional Change, 78 IND. L.J. 363 (2003).

23. See Jonathan Groner, Election Fight Lights Spark Under the Right, LEGAL Times, Dec. 4, 2000 , at 20 .

24. See Abraham Lincoln, First Inaugural Address, in 4 The Collected Works of Abraham LinColn 262, 268 (Roy P. Basler ed., 1953); Abraham Lincoln, Sixth Debate with Stephen A. Douglas, in 3 The Collected Works of Abraham Lincoln 245, 255 (Roy P. Basler ed., 1953).

25. See Franklin Roosevelt, Draft Speech on the Gold Clause Cases (Feb. 19, 1935), in F.D.R.: His Personal Letters, 1928-1945, 459-60 (Elliott Roosevelt ed., 1950).

26. Chief among these is whether popular constitutionalism (the view that the people should have a major role to play in constitutional interpretation) differs from departmentalism (the view that the 
both sides of the issue should be sufficient to show that judicial supremacy is not a simple left versus right or liberal versus conservative or Democrat versus Republican issue. At times some of the contemporary critics of judicial review have chosen simply to ignore those holding similar positions but from different political perspectives, but wishing won't make it so, and it is important to recognize that contemporary defenders as well as critics of judicial supremacy exist across the political and ideological spectrum. Tempting as it is for some to see the tide of judicial supremacy as basically a "Rehnquist Court" 27 or "conservative"28 agenda, the facts belie such a characterization. The very existence of odd political alliances, however much they may be ignored, is simply evidence of the enduring and fundamental importance of the issue.

II

\section{The Negative Constitution}

With these preliminaries out of the way, let us begin by examining a few exemplary Supreme Court cases, cases selected in order to make a point about the role of the courts. More precisely, these cases present a picture of judicially enforced constitutional limitations that is a picture not of wise judges overruling the actions of foolish legislators and executive officials, but rather is one stressing the importance of second-order constraints on the first-order decisions of often wise and often well-meaning members of the legislative and executive branches.

Our first case is Palmore v. Sidoti, ${ }^{29}$ in which a unanimous Supreme Court made clear that it was constitutionally impermissible under the Equal Protection Clause for a judge in a contested custody proceeding to take into account potential effects on the child stemming from a parent's remarriage to a person of a different race. Whatever the consequences for a child of being a member of an interracial family, the Court ruled, those conscquences could not as a matter of constitutional law be permissibly considered by a judge acting in the name of the state.

Congress and the president should have interpretive authority equal to or greater than that of the Supreme Court or that each of the three branches should have interpretive supremaey within its own sphere of operations). Compare Kramer, supra note 1, with Edward S. Corwin, Court Over Constitution: A Study of Judicial Review as an Instrument of Popular Government 15 (1938). See also Barkow, supra note 3, at $323 \mathrm{n} .529$; Whittington, supra note 3 , at 782-83. As will become apparent, my arguments against popular constitutionalism apply with almost equal force to departmentalism.

27. See Post \& Siegel, supra note 16, at 1945-46, 2058. Post and Siegel, however, appear to argue that accepting a strong congressional role in delineating the contours of the Fourteenth Amendment through Section 5 is compatible with Cooper $v$. Aaron-style assertions of judicial supremacy. See Post \& Siegel, supra note 16, at 2032-39. Seeing Section 5 as but a narrow exception to a general rule of judicial supremaey, however, seems in some tension with the overall antisupremacist tone of Post and Siegel's arguments.

28. Kramer, supra note 1 , at 964-65.

29. 466 U.S. 429 (1984). 
We do not know for sure what motivated the trial judge in Palmore. It may well have been simple racism or an objection on related grounds to the very idea of interracial marriage. But there is no indication of such a patently invidious judicial motivation in the record, and thus nothing in the record excludes the alternative explanation that perhaps the judge, while decrying racism and decrying aversion to interracial marriage, nevertheless believed it wrong to conscript juveniles as the front-line soldiers in the battle against racism. The judge might well have believed that being a child of an interracial couple, in the United States in 1983, would be especially difficult for a child, not because interracial marriage was wrong, but because too many people in society wrongly believed it wrong. With that being the case, the trial judge might well have believed that placing the child with the interracial couple may not have been in the "best interests of the child" however much such an act, when combined with large numbers of similar decisions, would nevertheless have been in the best interests of society.

At the heart of the Supreme Court decision in Palmore is the view that, even under this benign understanding of the motivations underlying the original trial court decision, the decision was constitutionally impermissible. However well-meaning the trial judge might have been, however much the judge might sincerely have believed that such a decision would be in the best interest of the child, and however much such a decision might actually have been in the best interests of the child, the decision could not stand.$^{30}$ If race is a suspect classification, the Court concluded, then it is presumptively impermissible to use race as a factor not only when its use reflects racism, but even when it does not. ${ }^{31}$

The same dynamic of imposing wise second-order constitutional restrictions even on equally wise first-order policy decisions is presented in an amusing but obscure dormant commerce clause case called Bacchus Imports, Ltd. $v$. Dias. ${ }^{32}$ At the heart of the case was a brandy called okolehao, made from a plant (called ti) indigenous to Hawaii and found nowhere else, and also a Hawaiian wine made not from grapes but from pineapple, a staple of the Hawaiian agricultural industry rarely grown elsewhere in the United States. As might bc expected, Hawaiian pineapple wine-for reasons of familiarity, heritage, and, presumably, taste-was at a competitive disadvantage in its competition with, for example, California cabernet and French Bordeaux. Presumably much the same could be said about brandy made from the ti plant. In order to assist its local industry,

30. That a full societal acceptance of interracial marriage would be a good thing does not entail that it would be good for every child of such a marriage during the transition to a better societal state of affairs.

31. I do not mcan to suggest that Palmore is germane to the debate about affirmative action and the permissibility of noninvidious racial classifications. My discussion here is only about what Palmore means within the particular category of racial classifications to which it applies.

32. 468 U.S. 263 (1984). 
and thus to assist indigenous pineapple farmers and ti distillers, Hawaii granted Hawaiian pineapple wine ${ }^{33}$ and okolehao exemptions from various state taxes, exemptions not available for the wines of France, Italy, California, and New York, nor for the brandies of Spain, Germany, Switzerland, and Poland.

As with the trial judge in Palmore, there is no reason to believe that either the governor or the legislature of Hawaii had evil motives. The legislature and the governor presumably sought to do what they thought they had been elected, in part, to do, which was to provide tangible support for local products and local industries and to foster the establishment of a strong financial base for local products. Yet however noble those motives may have been for the Hawaiian citizenry, they also constituted exactly the kind of explicit protectionism that even the narrowest reading of the dormant commerce clause ${ }^{34}$ does not countenance. Thus a majority of the Court had little difficulty in striking down the preferential tax exemption.

Now consider the collection of 1977 and 1978 cases, some commencing in federal courts and others in state courts, that go under the heading of the "Skokie" controversy. ${ }^{35}$ Led by a man named Frank Collin, the American Nazi Party proposed a march, complete with jackboots, swastikas, and all the rest, in Skokie, Illinois. The town is a suburb of Chicago disproportionately populated by survivors of the Holocaust and selected by Collin and his Nazi compatriots as the venue for their march for precisely that reason. Understandably incensed, and desirous of protecting their constituents from the targeted pain that the march would cause, the mayor and other officials of Skokie sought by all possible means to ban the march. They attempted to deny a permit, to impose onerous insurance requirements, and in various other ways to prevent or to minimize the harm to many Skokie residents that would ensue from the march.

As is now well known, these efforts on the part of Skokie officials were unavailing. Both state and federal courts, primarily on the authority of Cohen v. California, ${ }^{36}$ Police Department of Chicago v. Mosley, ${ }^{37}$ and

33. The statute referred to "fruit wine," but the Supreme Court, relying on both unmistakable legislative intent and the actual operation of the tax, coneluded that the tax exemption in both intent and in operation was limited to pineapple wine and extended neither to wine made from grapes (which were not fruits for purposes of the tax statute) nor to wine made from fruits other than pineapple.

34. See West Lynn Creamery, Inc. v. Healy, 512 U.S. 186, 213-16 (1994) (Scalia, J., concurring in the judgment).

35. Collin v. Smith, 578 F.2d 1197 (7th Cir. 1978), stay denied, 436 U.S. 953 (1978), cert. denied, 439 U.S. 916 (1978); Nat'l Socialist Party of Am. v. Village of Skokie, 432 U.S. 43 (1977) (per curiam). For additional discussion of these cases, see ARYEH NEIER, DefENding MY Enemy: American Nazis, the Skokie Case, and the Risks of Freedom (1979); Lee C. Bollinger, The Skokie Legacy: Reflections on an "Easy Case" and Free Speech Theory, 80 MicH. L. REv. 617 (1982); and David Goldberger, Skokie: The First Amendment Under Attack By lts Friends, 29 MerCER L. REv. 761 (1978).

36. 403 U.S. $15(1971)$.

37. 408 U.S. 92 (1972). 
Brandenburg $\mathcal{V}$. Ohio, ${ }^{38}$ held that such attempts to protect the citizenry from viewpoint-based harm constituted fundamental violations of the First Amendment, a conclusion that a clear majority of the Supreme Court found sufficiently self-evident that it refused to grant even a full hearing on the merits, denying certiorari in the federal case ${ }^{39}$ and dismissing their appeal for want of a substantial federal question in the state case. Once again, it is hard to maintain that the primary officials were foolish or selfish, but it is equally hard to deny that their actions were, under the existing law, plainly unconstitutional.

Finally there is the 1965 case of Griffin v. California. ${ }^{40}$ Even in 1965 it was acknowledged to be an unthinkable violation of the Fifth Amendment privilege against self-incrimination for the prosecution to call the defendant to testify in a criminal case. ${ }^{41}$ Nevertheless, the prosecutor in Griffin, as part of his closing argument, offered the empirically probable observation that guilty defendants were more likely to refuse to testify than innocent ones and asked the jury to take this into account as they weighed all of the evidence in the case.

Although commenting on the inferences that might be drawn from a defendant's constitutionally protected refusal to testify is seemingly based on highly plausible probabilistic conclusions, and although such commentary is permitted in the vast number of common law countries that recognize the privilege against self-incrimination, ${ }^{42}$ the Supreme Court would have none of it. Seeking to give the constitutional guarantee functional as well as literal protection, the Court ruled with little controversy that allowing such commentary would functionally negate the effect of a defendant's claim of a constitutional right and might deter defendants from exercising a right so plainly protected.

All four of these cases, and many others like them, share two important features. First, Palmore, Bacchus Imports, and the Skokie cases were straightforward applications of constitutional principles that were and are widely considered sound. And Griffin was a relatively uncontroversial supplementary principle necessary to protect an equally uncontroversial primary principle. Second, and more important, none of the principal government protagonists - the trial judge in Palmore, the Hawaii legislature

38. 395 U.S. 444 (1969) (per curiam).

39. Although denials of certiorari are, of course, not decisions on the merits, it is inconceivable that the Court was not aware of the signal it was sending in refusing even to hear the challenge from the Seventh Circuit decision.

40. 380 U.S. 609 (1965).

41. The very unthinkability of the view that the Fifth Amendment could allow the prosecution to call the defendant to the stand in a criminal case produces the fact that there is no citation to support this proposition.

42. See, e.g., R. v. Andrews [1992] 3 N.Z.L.R. 62. 
and governor in Bacchus Imports, the mayor and village council in Skokie, and the prosecutor in Griffin-were bad or self-aggrandizing people seeking to abuse or increase their power. Rather, all of these officials were, by most accounts, honest and well-meaning policymakers making sound, firstorder policy decisions designed to serve the legitimate interests of their primary constituencies.

That these officials were making sound first-order policy decisions does not necessitate the conclusion that those decisions were constitutionally permissible. That is why the soundness, honesty, and publicspiritedness of their first-order decisions does not protect them from invalidation on the second-order grounds that we label "constitutional." But the correct constitutional invalidation of even such seemingly wellintentioned legislative, executive, and judicial decisions calls into question an image of constitutional adjudication that is primarily about keeping bad people from doing bad things in pursuit of their own selfish or crassly political interests. ${ }^{43}$ To be sure, numerous constitutional decisions fit this mold ${ }^{44}$ but they do not exhaust the universe of constitutional decisions. Palmore, Bacchus Imports, Skokie, and Griffin represent the even more important set of instances in which constitutional rights exist not to keep bad people from doing bad things, but rather to keep good people from enacting sound first-order policies (or even pursuing sound first-order principlcs) that have negative or self-defeating ${ }^{45}$ second-order, institutional, or long-term consequences. The governmental actions in each of these cases were invalidated not in the service of preventing evil or combating powerhungry officials, but in the service of protecting important long-term second-order values ${ }^{46}$ from erosion by good people making reasonable short-term decisions.

Decisions like these represent what we might call the "negative Constitution." These decisions, and in important respects the constitutional provisions and principles they embody, are not so much about reflecting the deepest aspirations, goals, and ideals of a polity. Nor are they about empowering democratic and deliberative decision making. Rather, they are about entrenching those long-term values-not necessarily the most important of our values ${ }^{47}$ - that are especially likely to be vulnerable in the short term. Constitutional entrenchment, therefore, creates second-order

43. A good example of this common view is Cass $\mathrm{R}$. Sunstein, Naked Preferences and the Constitution, 84 Colum. L. REv. 1689, 1689-92 (1984).

44. See, e.g., United States v. Nixon, 418 U.S. 683 (1974); New York Times Co. v. Sullivan, 376 U.S. 254 (1964); Grosjean v. Am. Press Co., 297 U.S. 233 (1936).

45. See Adrian Vermeule, Hume's Second-Best Constitutionalism, 70 U. CHI. L. Rev. 421, 435 (2003)

46. See Sunstein \& Ullman-Margalit, supra note 2 , at 7 .

47. The Third and Seventh Amendments, protecting values that seem far less than fundamental, are good cautions against those who too easily see in the Constitution a statement of what is most important to the polity. 
constraints on wise and well-meaning first-order decisions. Recognizing that good people doing good things often produce bad collective long-term consequences, or that good people doing good things often neglect nonconsequentialist values, ${ }^{48}$ the negative Constitution establishes a series of restrictions targeting good decisions as well as evil ones and functions as a check on even the most well-meaning democratic decision making.

These second-order restrictions may have a variety of foundations. For those who believe that welfare and utility maximization do not exhaust the universe of human values, some of these restrictions-the prohibition on cruel and unusual punishments, the protection of free exercise of religion, the guarantee of equal protection of the laws, some dimcnsions of freedom of speech - can be understood as deontological side-constraints on utility maximization. ${ }^{49}$ But even from an unconstrained consequentialist perspective, these and other second-order constraints can still be understood as rule-consequentialist side-constraints on act-consequentialist maximization, ${ }^{50}$ or as ways of dealing with Prisoners' Dilemma and other problems of collective action. But whatever their deepest source, the rights, values, and procedures protected by the negative Constitution are best understood not necessarily as the most important of our rights, and certainly not as a comprehensive statement of our most fundamental hopes and ideals, but as the interests that appear to be in the greatest jeopardy from strict first-order decision making.

\section{III}

\section{Enforcing the Negative Constitution}

In theory nothing about enforceability or the role of the courts flows from recognizing the negative aspects of the Constitution. The "people themselves," as Professor Kramer puts it, could, after all, recognize and self-enforce wise second-order constraints on their own wise first-order policy preferences. Through self-restraint, they could enforce those secondorder limits against their own short-term interests as they make, whether directly or through elected representatives, their first-order policy decisions.

Yet although it is theoretically possible for people to enforce rules upon themselves, ${ }^{51}$ in numerous walks of life we worry about the strength

48. See generally Ronald Dworkin, Taking Rights Seriously 184-205 (1977).

49. See DWOrkin, supra note 48; Robert Nozick, ANarchy, State, and Utopia 28-35 (1974) (developing the idea of rights as moral side-constraints on utility maximization); JUDITH JARvis THOMSON, The Realm OF Rights (1990).

50. On rule utilitarianism and rule consequentialism, see, among recent works, BRAD HoOKER, Ideal Code, Real World: A Rule-Consequentialist Theory of Morality (2000); and Conrad D. Johnson, Moral Legislation: A Legal-Political Model for Indirect Consequentialist REASONING (1991).

51. See Thomas C. Schelling, Enforcing Rules on Oneself, 1 J.L. Econ. \& OrG. 357 (1985). 
of will and mental separation that would make this possible. We do not allow judges or jurors to sit on cases in which their own interests are affected. We appoint inspectors general and divisions of internal affairs and special prosecutors to prevent officials from investigating themselves. We expect public officials to avoid conflicts of interest, no matter how honest we think they are. And in numerous other ways, the principle of English natural justice-nemo debet esse judex in propria sua causa (no man should be judge of his own cause) ${ }^{52}$ - pervades our principles of institutional design.

At times externally-enforced rules may be necessary in order to protect a majority's own long-term interests from that majority's short-term desires. Just as we often enlist external enforcers-personal trainers, for example ${ }^{53}$ - to make sure that our long-term interests do not fall prey to short-term weakness of the will, so too does the same phenomenon apply to governmental decisions. The very idea of requiring a super-majority for a constitutional amendment reflects this instinct, ${ }^{54}$ and we can see this in constitutional decisions as well. I.N.S. v. Chadha, ${ }^{55}$ for example, was at one level about "formal" as opposed to "functional" approaches to separation of powers, ${ }^{56}$ but at a deeper level it was about preserving the people's longterm constitutional arrangements against the same people's short-term desires to circumvent the amendment process in order to make government work more smoothly. Much the same can be said about Bowsher v. Synar, ${ }^{57}$ invalidating a constitutionally dubious but pragmatically useful way of dealing with budget deficits. Indeed, the fact that the federal budget was in surplus less than ten years after the passage of the invalidated Gramm-Rudman-Hollings Act supports the proposition that measures are often less necessary than popular or legislative majorities believe them to be. Freedom of the press may also be a good example, for the short-term desire to restrict the unpleasant voice, especially when it seems (or actually is) wrong, may be inconsistent with the long-term interest in keeping the institution of the press free and strong.

The importance of external constraint is especially apparent in the context of the protection of persistently unpopular and systematically

52. See R. v. Barnsley Licensing Justices, 2 Q.B. 167 (A.C. 1960); R. v. Hertfordshire Justices, 6 Q.B. 753, 115 Eng. Rep. 284 (1845); Dimes v. Grand Junction Canal 3 H.L.C. 759, 88 Rev. Rep. 310 (H.L. 1852); O. Hood Phillips \& Paul Jackson, O. Hood Phillips' Constitutional and AdMinistrative LaW 603-04 (6th ed. 1978).

53. Those of us with big egos and a pathological unwillingness to be thought weak often find that announcing our future plans-to quit smoking or to ride a bicycle across the United States-to a large number of friends is a highly effective way of guarding against weakness of the will.

54. U.S. Const. art. V.

55. 462 U.S. 919 (1983).

56. See Peter L. Strauss, Formal and Functional Approaches to Separation-of-Powers Questions-A Foolish Inconsistency?, 72 CoRnell L. Rev. 488 (1987).

57. 478 U.S. 714 (1986). 
under-represented interests-not only the discrete and insular minorities of the Carolene Products footnote ${ }^{58}$ but also those whose unpopularity spans traditional ideological divisions (atheists, flag burners, child pornographers, and those charged with crimes, for example). With respect to such individuals, their rights will probably never be seriously represented by popular or legislative majorities, and it should be no surprise that the rights these minorities claim are those for which judicial supremacy has made the greatest difference.

Examples of the effects of judicial supremacy hardly occupy the entirety of constitutional law. As the proponents of popular constitutionalism properly claim, it is simply not plausible to argue that all of the Supreme Court's decisions are counter-majoritarian, nor that the Court is unaware of the potential repercussions if a high percentage of its decisions diverges too dramatically from the popular or legislative will. Nevertheless, there is no indication that the Court uses its vast repository of political capital only to accumulate more political capital, and in many areas judicial supremacy has made not just a short-term difference, but a long-term difference as well. Perhaps most obvious is school prayer. For over forty years the Court has persisted in its view that organized prayer in public schools is impermissible under the Establishment Clause ${ }^{59}$ despite the fact that public opinion is little more receptive to that view now than it was in $1962 .{ }^{60}$ So too with flag burning, where the Court's decisions from the late $1960 \mathrm{~s}^{61}$ to the present have remained dramatically divergent from public and legislative opinion. ${ }^{62}$ Or consider child pornography, where the Court's decision in Ashcroft v. Free Speech Coalition ${ }^{63}$ flew in the face of an overwhelming congressional majority approving the extension of existing child pornography laws to virtual child pornography. Similarly, in the regulation of "indecency," the Court has spent well over a decade repeatedly striking down acts of Congress that enjoyed overwhelming public and

58. United States v. Carolene Prods. Co., 304 U.S. 144, 152 n.4 (1938).

59. Santa Fe Indep. Sch. Dist. v. Doe, 530 U.S. 290 (2000); Lee v. Weisman, 505 U.S. 577 (1992); Wallace v. Jaffree, 472 U.S. 38 (1985); Abington Sch. Dist. v. Schempp, 374 U.S. 203 (1963); Engel v. Vitale, 370 U.S. 421 (1962).

60. National Election Studies polls show that even as of 1998, only sixteen percent of the American population agreed that there should be no prayer in public schools. Nat'l Election Studies, NES Guide to Public Opinion And Electoral Behavior, available at http://www.umich.edu/ nes/ nesguide/toptable/tab4c_3b.htm (last visited Feb. 28, 2004). When the issue is phrased in terms of agreement with the core of the holding in Schempp, the agreement rate is higher, but still only thirtyseven percent, no higher than it was in 1982. See Nat'1 Opinion Research Ctr., Bible Readings in Public School, available at http:// lstam.umn.edu/main/pubop/biblereading.htm (last visited Feb. 28, 2004).

61. See United States v. Eichman, 496 U.S. 310 (1990); Texas v. Johnson, 491 U.S. 397 (1989); Spence v. Washington, 418 U.S. 405 (1974); Smith v. Goguen, 415 U.S. 566 (1974); Street v. New York, 394 U.S. 576 (1969).

62. See First Amendment Online, Flag Burning, at http://1stam.umn.edu/main/pubop/ flag-burning.htm (last visited Feb. 29, 2004) (giving various poll results).

63. 535 U.S. 234 (2002). 
congressional support. ${ }^{64}$ Most dramatic of all, however, is criminal procedure, where the Supreme Court's decision in Dickerson v. United States, ${ }^{65}$ invalidating a congressional attempt to overrule Miranda $v$. Arizona ${ }^{66}$ underscores the persistent gap in concern for defendants' rights between Congress and the public, on the one hand, and the Supreme Court, on the other.

\section{IV \\ JUDiCIAL SUPREMACY Without IlLuSION}

It turns out, therefore, that the case for judicial authority or, to put it differently, for overridable judicial supremacy, need not depend, as Professor Kramer and others appear to suppose, on the view that the people and (mutatis mutandis) legislatures are stupid, ignorant, especially selfish, or especially driven by passion rather than reason. Admittedly, such attitudes about the population and their elected representatives are hardly absent from the academy, the judiciary, and the intelligentsia. And there can be little doubt that such attitudes drive some claims of judicial supremacy. Yet it is usually a mistake to argue by psychologizing one's opponents, and the argument in the foregoing sections should make it clear that the best argument for judicial authority is not dependent either upon a dim view of the people or upon a glorified view of the judiciary, ${ }^{67}$ no matter how common such views may be.

In maintaining that the question of judicial supremacy is a "matter of sensibility,"68 Professor Kramer, like others before him, ${ }^{69}$ assumes that it would be impossible to believe in judicial supremacy without having a largely negative view of popular (or legislative ${ }^{70}$ ) governing capacity. Yet however widespread such a negative view may be, ${ }^{71}$ it is a mistake to assume that the sensibilities of the faculty lounge necessarily drive the argument for judicial supremacy, and a larger mistake to take on the weakest rathcr than the strongest argument for judicial supremacy. The strongest argument, as we have seen, is not the argument from popular

64. See, e.g., Reno v. Am. Civil Liberties Union, 52I U.S. 844 (I997); Sable Communications of CaI., Inc. v. Fed. Communications Comm'n, 492 U.S. I15 (1989).

65. 530 U.S. 428 (2000). For context, sce Neal Devins, Asking the Right Questions: How the Courts Honored the Separation of Powers by Reconsidering Miranda, 149 U. PA. L. REv. 251 (2000).

66. 384 U.S. 436 (1966).

67. For an cffective argument against such glorified views, see Roderick M. Hills, Jr., Are Judges Really More Principled than Voters?, 37 U.S.F. L. REv. 37 (2002).

68. Kramer, supra note 1, at 1002.

69. See, e.g., Richard D. Parker, "Here, the People Rule": A Constitutional Populist MANifesto (1994).

70. See generally Jeremy Waldron, Law and Disagreement (1999); Jeremy Waldron, The Dignity of Legislation (1999).

71. For discussions of the issue far more serious and nuanced than one is likely to find in judicial chambers or in the faculty common room, see the various arguments in Public Ignorance, 12 CRITICAL REv. 397 (1998). 
incompetence, but rather a combination of two different arguments, ${ }^{72}$ neither of which presupposes or requires a negative view of the populace. ${ }^{73}$

The first of these arguments is the familiar one about checks on selfinterest. To believe that people vote (and in other ways participate in governance) largely on the basis of their self-interest is not to deny the same phenomenon for judges, ${ }^{74}$ executives, administrators, or academics. It is to say only that at the core of the strongest argument for judicial supremacy, and the argument dependent neither on an unrealistically rosy view of the judiciary nor on an unrealistically dim view of the electorate, is a recognition that the ability of the people to pursue their own interests in the name of public policy, like the ability of the members of the judiciary to pursue their own interests in the name of public justice, might plausibly be limited by introducing a source of countervailing power.

This argument is related to but not identical to the argument for second-order constraints on first-order policy preferences. Again, the belief that people have only a limited ability to impose such constraints on themselves is not a view about the limited abilities of people. Or, more accurately, it is not a view about the disproportionately limited abilities of the people when compared to the abilities of any other segment of society. First-order policies and preferences occupy the foreground of our phenomenology; ${ }^{75}$ and while the ability to look beyond this foreground is no more limited for the people as a whole than it is for university professors or members of the federal judiciary, nor is there reason to believe that it is less.

72. Actually, it is three arguments. The argument that settlement is intrinsically valuable, which Larry Alexander and I have developed elsewhere, is compatible with but different from the argumcnts I offer here. See Larry Alexander \& Frederick Schauer, Defending Judicial Supremacy: A Reply, 17 Const. Comment. 455 (2000); Larry Alexander \& Frederick Schauer, On Extrajudicial Constitutional Interpretation, 110 HARV. L. REv. 1359 (1997).

73. It also does not require the kind of positive view of the judiciary that one sees in, for example, Christopher L. Eisgruber, Constitutional Sel.F-Government (2001).

74. See Richard Posner, What Do Judges Maximize? (The Same Thing Everybody Else Does), 3 SUP. CT. ECON. REv. I (1993); Frederick Schauer, Incentives, Reputation, and the Inglorious Determinants of Judicial Behavior, 68 U. CIN. L. REv. 615 (2000).

75. This was one of the basic insights of Legal Realism, set out most cxplicitly and least subtly in Jerome Frank, Law and the Modern Mind (1930); see also Dan Simon, A Psychological Model of Judicial Decision Making, 30 Rutgers L.J. 1 (1998). When first-order policy preferences are strong, and formal legal guidance indeterminate, as with the small number of cases decided on the merits by the Supreme Court every year, first-order policy preferences appear to play the strongest role in explaining outcomes. See Jeffrey A. Segal \& Harold J. Spaeth, The Supreme Court and the Attitudinal Model (I993); James L. Gibson, Judges' Role Orientations, Attitudes, and Decisions: An Interactive Model, 72 Am. Pol. ScI. Rev. 911 (1978); Jeffrey A. Segal, Separation-ofPowers Games in the Positive Theory of Congress and Courts, 91 Am. Polı. SCI. Rev. 28 (1997). 


\section{$\mathrm{V}$}

\section{On the Distinction Between Making and Enforcing Norms}

At times it appears that neither Kramer nor others, especially Waldron, ${ }^{76}$ would disagree with the foregoing. They acknowledge that judicial supremacy may be appropriate for enforcing those clear rights that the people themselves have at earlier times expressly recognized. This is merely, but properly, a recognition that an important dimension of constitutionalism, a dimension captured by the image of Ulysses binding himself to the mast, is one in which the people themselves decide that they wish to be constrained in the future against their own strong but short-term policy preferences. Thus, Kramer and others appear to accept that textually explicit and precisely demarcated rights (such as the right not be convicted of treason except by the testimony of two witnesses or the right to a trial by jury in all criminal and most civil cases) might appropriately be enforced by the judiciary acting simply as the agent of the people for the enforcement of rights that the people themselves have created at an earlier time.

Not so in many other cases, Kramer, Waldron, and others argue. ${ }^{77}$ When the issue is filling in the indeterminate contours of "due process of law,"78 "equal protection of the laws," "cruel and unusual punishments," "freedom of speech ... [and] press," for example, they insist that the judiciary cannot plausibly be seen as merely the enforcing agent for decisions made by the people in earlier times. Even if a strong, preeminent, and deference-entitled judiciary is the appropriate institution for enforcing pre-designated rights, it is something else again when the task is best understood as deciding what rights there will be rather than how to enforce the rights that exist. Decisions about applying "equal protection of the laws" to gender, ${ }^{83}$ sexual orientation, ${ }^{84}$

76. See Waldron, Law and Disagreement, supra note 70 ; Waldron, The Dignity of LEGISLATION, supra note 70.

77. This appears to be one of the running themes in Post, supra note 16.

78. U.S. ConST. amend. V; U.S. ConST. amend. XIV, § 1 .

79. U.S. Const. amend. XIV, § I.

80. U.S. Const. amend. VIII.

81. U.S. Const. amend. 1.

82. Id.

83. Craig v. Boren, 429 U.S. 190 (1976); Frontiero v. Richardson, 411 U.S. 677 (1973); Reed v. Reed, 404 U.S. 71 (1971).

84. Lawrence v. Texas, 539 U.S. 558 (2003); Romer v. Evans, 517 U.S. 620 (1996); Bowers v. Hardwick, 478 U.S. 186 (1986). For many of us, the recent decisions of the Supreme Judicial Court of Massachusetts on gay and lesbian marriage provide a powerful example of how courts may on occasion determine the contours of vague constitutional provisions to the benefit of relatively powerless minorities in ways far removed from contemporaneous political, popular, legislative, or executive movement. See In re Opinions of the Justices to the Senate, 802 N.E.2d 565 (Mass. 2004); Goodridge v. Dep't of Pub. Health, 798 N.E.2d 941 (Mass. 2003). Popular constitutionalists might argue that better long-term results for gays and lesbians could have been secured if the Supreme Judicial Court had waited, or might argue that the detrimental effects of judicial supremacy outweigh the benefits, such that it is better to deny the authority than to grant it. Or they might claim that the arguments for 
age ${ }^{85}$ alienage ${ }^{86}$ and affirmative action, ${ }^{87}$ for example, are the foundational questions that democracy demands be made by the people and not a small coterie of judges or even a large coterie of lawyers, so these critics say. So too with questions regarding whether to apply "due process of law" to contraception, ${ }^{88}$ abortion, ${ }^{89}$ and sexual conduct; ${ }^{90}$ whether to apply the prohibition on "cruel and unusual punishments" to capital punishment;" and whether to allow harsh sentences for multiple offenders. ${ }^{92}$ In all of these instances, and many more, so the argument goes, the enforcement model is unavailing, and the question of what these wildly indeterminate clauses mean is not very different from the question of what a constitution should say in the first place, a question that in a democracy must be answered by the people or their responsive representatives, not by an elite of lawyers and judges.

Although it may not be immediately apparent, this view rests on a particular and highly controversial view about rights. More particularly, it is premised on the view that rights and interests (or policies) are more continuous than the standard picture of rights as side-constraints assumes, ${ }^{93}$ and that, to caricature this view slightly, a right is little more than an interest pounding its fist on the table. Under this view, rights, like interests, are ultimately created by law, rather than existing antecedent to law and then being enforced by law. If rights, even if not exactly "nonsense on stilts," exist by virtue of law, then it should come as no surprise that the ultimate power to make law in a democracy - the people - might be expected to be the ultimate power to decide what rights we are to have and what rights the courts are to enforce. Moreover, as Waldron and to a lesser extent Kramer

judicial supremacy are peculiar to particular courts and particular times (on this, see Frederick Schauer, Neutrality and Judicial Review, 23 L. \& PHIL. 217 (2003)), such that nothing they say about the Supreme Court of the United States applies to the Supreme Judicial Court of Massachusetts. But unlike other issues on which judicial action in general and Suprcme Court action in particular was so intertwined with popular and political movements, see GeRALD N. ROSENBERG, THE Hollow Hope (1991), as to make questions of causality difficult to disentangle, it seems clear that the Supreme Judicial Court was well ahead of popular and political opinion. As a result, its actions cannot plausibly be described as other than "juricentric," and we await the arguments attempting to reconcile objections to judicial supremacy with acceptance of the judicial outcomes in the Massachusetts case.

85. Massachusetts Bd. of Ret. v. Murgia, 427 U.S. 307 (1976).

86. In re Griffiths, 413 U.S. 717 (1973); Graham v. Richardson, 403 U.S. 365 (1971).

87. Grutter v. Bollinger, 539 U.S. 306 (2003); Adarand Constructors, Inc. v. Peña, 515 U.S. 200

(1995); City of Richmond v. J.A. Croson Co., 488 U.S. 469 (1989).

88. Griswold v. Connecticut, 381 U.S. 479 (1965).

89. Roe v. Wade, 410 U.S. 113 (1973).

90. Lawrence v. Texas, 539 U.S. 558 (2003).

91. Eddings v. Oklahoma, 455 U.S. 104 (1982); Lockett v. Ohio, 438 U.S. 586 (1978); Gregg v. Georgia, 428 U.S. 153 (1976); Furman v. Georgia, 408 U.S. 238 (1972).

92. Lockyer v. Andrade, 538 U.S. 63 (2003).

93. See Richard H. Fallon, Jr., Individual Rights and the Powers of Government, 27 GA. L. REv. 343, 343-44 (1993); Richard H. Pildes, Why Rights Are Not Trumps: Social Meanings, Expressive Harms, and Constitutionalism, 27 J. LEGAL STud. 725 (1998). There is some flavor of this, although in a milder form, in Post \& Siegel, supra note 16, at 1977, 2021. 
argue, if actual disagreement about rights makes realism about rights a practically implausible position, then acting as if rights pre-exist our decisions about them is unfaithful to our actual experience with rights in a world of disagreement.

By contrast, if rights, or at least some rights, are antecedent to the Constitution (whether written or otherwise), then it does not follow that such rights do not exist unless the Constitution or the supreme lawmaking power recognizes them. Indeed, many of the debates about constitutional theory in the 1970s and 1980s focused on this very issue ${ }^{94}$ and on the hotly contested possibility that explicit recognition of a right in a written constitution was not a necessary condition for judicial enforcement of that right.

We should not make too much of this point. Considerations of institutional design might suggest that granting such judicial power would be mistaken even if rights do exist prior to the Constitution. Such considerations would include, for instance, the possibility that courts empowered to enforce unenumerated rights would make more mistakes of recognition of nonrights than courts not so empowered would make mistakes of nonrecognition of real rights. Moreover, the values of majoritarian selfgovernance, which count for something in the calculus even if those values are not the only ones of importance, might constrain our willingness to grant to nonmajoritarian courts the jurisdiction to recognize unenumerated rights even if those rights in fact do exist.

This is all familiar territory. Still, rehearsing the familiar exposes the fact that recognizing that a particular right (privacy, say) is not logically entailed by a general right (due process) does not eo ipso produce the conclusion that delineating the scope of due process must be left to the people. That conclusion follows only if, at best, rights do not exist antecedent to the constitution; or if the public's right to self-governance is lexically prior to all other rights; or if, as a contingent matter of institutional design, courts are not to be trusted with the task of rights recognition. These last two factors may well be sound, but they merely reframe what is exactly the matter at issue. Consequently, recognizing that delineating the contours of abstractly formulated rights is different from enforcing delineated rights gets us less far than we might think in directly confronting the question of judicial supremacy. Moreover, it is possible that the same considerations that lead to judicial preeminence in enforcing pre-existing rights would produce the same conclusion when the question is about empowering the

94. See. e.g., John Hart Ely, Democracy and Distrust: A Theory of Judicial Review (1980); Michael. J. Perry, The Constitution, the Courts, and Human Rights (1982); Robert H. Bork, Neutral Principles and Some First Amendment Problems, 47 IND. L.J. 1 (1971); Thomas C. Grey, Do We Have an Unwritten Constitution?, 27 Stan. L. REv. 703 (1975); David A.J. Richards, Human Rights as the Unwritten Constitution: The Problem of Change and Stability in Constitutional Interpretation, 4 U. DAYTON L. REv. 295 (1979); Frederick Schauer, An Essay on Constitutional Language, 29 UCLA L. REV. 797 (1982). 
delineation of abstractly formulated rights. If, as Ronald Dworkin has insisted, one class of rights is best understood as rights against the majority, ${ }^{95}$ a characterization that provides perhaps the best understanding of many equality rights and a fair number of free speech, free exercise, criminal procedure, and due process rights as well, then the same arguments about second-order constraints on first-order policy preferences that were developed above would also apply as much to rights delineators as to rights enforcers. Just as we might expect anyone-including judges, lawyers, members of Congress, the President, and ordinary citizens-to be systematically deficient at the task of acting against self-interest, so, too, might we expect majorities to have the same systematic deficiencies. Again, this view is not to be understood as being especially critical of the competence of majorities or of the people. It does recognize, however, that the same arguments for being reluctant to let police officers, presidents, attorneys general, and lawyers police themselves would also apply to the policing of majorities and the policing of the people, for this is a large part of what rights against majorities do.

\section{VI \\ The Modest Constitution}

Even if we understand constitutional decision making as working out and not just enforcing rights-based side-constraints, ${ }^{96}$ an important conclusion emerges from the foregoing: the Constitution is not the primary forum in which the people make the bulk of their most important decisions about policy and principle. And in this conclusion lies perhaps the major divide between those who support and those who are skeptical about judicial primacy in constitutional adjudication.

Under one view, common among American constitutionalists since the 1970s, the Constitution is America's civil religion, ${ }^{97}$ defining and shaping who we are and what we wish to be. The Constitution is and always has been the repository of American-ness, the forum for our deliberation and discourse about our hopes and aspirations, and the vehicle by which we crystallize our fears and dreams. ${ }^{98}$

This view of the role of the Constitution provides fertile ground for skepticism about judicial supremacy. If the Constitution is so central to what we are, is so constitutive of everything that we the people stand for, and is the vehicle for the formation and transformation of national identity,

95. DwORKIN, supra note 48 , at 204-05.

96. And sometimes courts have a special role to play even when rights are not at issue, as with dealing with the coordination and cooperation issues that lie at the heart of the dormant commerce clause.

97. See Sanford Levinson, Constitutional Faith (1988).

98. See Post, supra note 16, at 30,37; Post \& Siegel, supra note 16, at 1980-84. 
then leaving such a central role in democratic self-governance to judges should be a source of concern. Such an allocation of power would involve an abdication of democratic governance itself.

Yet there is another view of the Constitution, one that is far more modest. The Constitution, although it does set out the basic structure of government and delineates the procedural rules by which that government will operate, says remarkably little about what the government should do, and that is as it should be. By and large, such central substantive decisions about public policy should be made in more public, more representative, and more deliberative forums, whether those forums be the chambers of legislatures or the more important and more diffuse networks by which public opinion is formed, reformed, and implemented. For all such tasks, the modest Constitution is appropriately a bystander. To believe in the modest Constitution is not to disagree with the popular constitutionalists about the primary locus for determining major questions of public policy. It is, instead, to disagree with the notion that when these questions are determined by the people the debate is or should be channeled through the Constitution. There are examples in which it is, to be sure, but just as the owner of a hammer needs to be wary of seeing every problem as a nail, so, too, does the constitutionalist-especially the American constitutionalistneed to be wary of seeing every problem as a constitutional one. ${ }^{99}$

Yet although the modest Constitution does not aspire to be at the center of all or even most debates of either policy or principle, there is good reason not to have a regime of unlimited legislative or popular sovereignty. Neither legislatures nor the people are best suited to recognize and enforce the necessary limits on their own power, nor are they well suited to implement and, if necessary, create the side-constraints on policy optimization that are so apparent in cases like the ones that commenced this Reply. Here, and arguably only here, it is popular (or congressional) supremacy and not judicial supremacy that is the problem. This is not because there is something wrong with the people, but rather because well-meaning and informed people pursuing policies that are, from their own perspective, well-meaning and informed, are still sometimes in need of an external check to ensure the aggregate common good. Sometimes this check exists

99. Thus the issue is antecedent to the question whether the Constitution is, as Professor Kramer puts it, "ordinary law." Kramer, The People Themselves: Popular Constitutionalism and Judicial Review 224 (2004). The antecedent question is whether we see the Constitution as the vessel into which much of the shape of the nation is poured, or from whieh much of that shape emerges, or by contrast whether we see the Constitution as more modestly being about the development of a certain category of side-constraints on the political process. It may be that choosing the latter produces the conclusion that the Constitution is best treated as ordinary law, and it may even be that the conclusion that the Framers and others did not view the Constitution as ordinary law produces some historical support for the former. But if the question is the largely nonhistorical one of institutional design, the Constitution as ordinary law (or not) is at best the conclusion rather than the premise. 
in the service of protecting systematically underrepresented interests, ${ }^{100}$ as the Supreme Court recognized at least as long ago as Carolene Products. ${ }^{101}$ Sometimes the check exists to apply the same constraints of conflict of interest in popular decision making as we apply in other settings. In still other cases, the check exists to resolve Prisoners' Dilemmas and related problems of cooperative behavior. The modest Constitution is focused on such tasks, ${ }^{102}$ and as long as it stays so focused, there is little danger that entrusting its enforcement to a strong judiciary supreme in its interpretations of the Constitution (a necessary condition for the task of imposing second-order constraints on even well-intended first-order policy preferences) will represent a substantial derogation of the idea of government and policy shaped largely by the people themselves. ${ }^{103}$

100. Professor Kramer follows Waldron in noting that there are a large number of obviously nontotalitarian societies-Great Britain, New Zealand, the Netherlands, Sweden, and France, for example-that survive quite nicely without judicial supremacy. Kramer, supra note 1, at 997. Yet it is surely relevant to the inquiry, one which Kramer rightly takes to be an empirical one, that on issues like criminal procedure, freedom of the press when it is irresponsible, freedom of speech for the truly evil (Nazis, Klansmen, and child pomographers, for example), and a strong separation between church and state that the United States diverges quite sharply from all the aforementioned countries in its protection of the relevant rights. It may be wrong for the United States to be so divergent, but setting these countries out as models suggests a willingness to accept fewer defendant's rights, free speech rights, free press rights, and separation of church and state rights than exist in the United States even in the Rehnquist Court era. Perhaps that is where the issue should be joined, for it may well be that it is in the domain of rights carried by systematically powerless litigants that the argument for judicial supremacy is strongest.

101. 304 U.S. at 152 n. 4 .

102. In this sense it is possible that $I$ have fewer differences with the popular constitutionalists than may appear at first sight. To believe in a modest constitution with judicial supremacy within its scope is not to object to the people and other branches playing the dominant role in the formation of national identity and the designation of enduring and fundamental values. In this sense, the popular constitutionalists and 1 have a common opponent: those who believe both that the Constitution is the repository for most of the important questions about society's values and that the courts are to be in charge of this process through the vehicle of judicial supremacy. Moreover, it is possible that at the heart of some objections to judicial supremacy is an unwillingness to relinquish the former view, that the Constitution really is pervasively substantively important. But if the Constitution's aspirations are to be understood (or created) more modestly, as serving a vital but narrow function, then judicial supremacy would seem less threatening.

103. A few words are perhaps in order about the decidedly nonhistorical approach 1 take here. While 1 embrace with enthusiasm both the lessons we can learn from history and the less instrumental value of knowing and understanding the past just for the sake of knowledge, to vicw history as having an authoritative role in contemporary issues of institutional design is to embrace a controversial view about the hold of the past on the present that requires deeper exploration than is possible here for me or, indeed, for any of the other participants in this Symposium. National institutional design is of course path dependent, and there can be no doubt that what the people and the Framers thought and did during the founding period has profoundly influenced the array of options now available to us. This said, however, the question about how we should now understand constitutionalism in general and American constitutionalism in particular as constrained or framed by views on those subjects in the past is highly contested, and my nonreliance on history here can be understood (in this Reply) as an unargued assertion about the nonauthoritativeness (not the nonwisdom) of the events or views of the founding period. 


\section{CONClusion}

It should come as no surprise that the debates about judicial supremacy track so closely the debates of earlier generations about judicial review and constitutional theory. ${ }^{104}$ These earlier debates were about the appropriate allocation of decision-making authority in a democracy and the more recent debates about judicial supremacy in interpreting the constitution are but one facet of this larger issue.

The larger issue, however, is framed here as a debate about the merits and demerits of popular constitutionalism. If constitutionalism is understood simply as governance, or grandly as the location for decisions about the fundamental and foundational values and ideals of a society, then judicial constitutionalism is an assault on self-rule itself, and dramatically inconsistent with most versions of democratic rule.

But if we understand constitutionalism more modestly, it is not about grandiose notions of self-rule or national identity. It is not even about what Alexander Bickel called "enduring values." 105 Rather, in its most important dimension, it is about the way in which self-rule is not only about rule but about self. And if in numerous other dimensions of life we recognize the importance of constraining as well as empowering the pursuit of selfinterest, we should not be appalled that this dimension of institutional design might be reflected in the design of democracy. When we recognize the importance of second-order constraints on first-order democratic preferences of both policy and principle, then constitutionalism in this more modest sense comes to the fore. The modest Constitution has ambitions that are narrower in scope but greater in force, and as a result judicial supremacy and the modest Constitution emerge as natural partners.

104. See Kramer, supra note 1 , at 1003 .

105. Alexander M. Bickel, The Morality of Consent (1975); Alexander Bickel, The Least Dangerous Branch: The Supreme Court at the Bar of Politics 24 (1962). 
